sanoa vielä kolmannella, John Kenneth Galbraithin sanoilla: "Ihmisen vapauttaminen ruumiillisesta työstä on aivan eri asia kuin hänen vapauttamisensa älyllisestä ponnistelusta, mitä tehtävää pidän ennenaikaisena."

Kirjan oikolukemisessa ja joissakin suomennoksen kohdissa on toivomisen varaa, mutta eivät ne lukemista haittaa.

Lukemisen aikaan ilmestyi Hannu Juuson ja Tuukka Tomperin vieraskynäkirjoitus (HS 18.3.2010) lasten filosofoinnista kouluopetuksessa. Kirjoitus on sukua McLarenin ajattelulle. Tomperi onkin esitellyt suomek- si Freireä ja toimittanut Sorrettujen pedagogiikan suomennoksen yhdessä Suorannan kanssa. Freire elää!

\section{Aarni Tuominen}

\title{
Sosiaalinen tila oppilaitoksen johtamisen haasteena
}

Ahonen Helena (2008). Rehtoreiden kertoma johtajuus ja johtajaidentiteetti. Jyvaskyla Studies in Education, Psychology and Social Research 352. Jyväskylän yliopisto

\section{S} osiaalisen tilan vaikutukset johtajuuteen ja johtamisidentiteettiin ovat uudehkoja johtajuustutkimuksen teemoja. Tarkasteltavassa tutkimuksessa ne nousevat konkreettisesta oppilaitosjohtamisen arjesta. Aineistosta käy ilmi, kuinka oppilaitoksen rehtori tasapainoilee sekä asiantuntijayhteisön johtajana että työsuoritusten toteuttamisen esimiehenä. Koulun johtamisen arkeen kytkeytyvät vielä sen ulkopuoliset sidosryhmät, joihin johtajalla on erityinen suhteensa. Nämä ryhmät määrittelevät erityisesti johtajuuden autonomiaa, valtaa ja päätöksenteon valtuutta.

Helena Ahosen väitöskirja pureutuu johtajuuden ja johtajuusidentiteetin rakentumiseen. Tätä tutkimusteemaa hän lähestyy oppilaitosrehtoreiden kertomien konkreettisten johtajuustoimien ja -tilanteiden kautta. Onkin mielenkiintoista seurata, miten hän rakentaa johtajien kertoman toimintaympäristön analyysistä johtajien identiteetin muodostumisen aineksia.
Tarkasteltavassa väitöskirjassa käytetään siis sosiaalisen tilan käsitettä johtajuuden analysoinnin välineenä. Tämä monimutkainen fyysis-psyykkinen ja sosiaalinen kokonaisuus määrittää johtajuutta ja samalla johtajuus määrittää ja muovaa sitä. Koska johtaja on osa sosiaalista toimintatilaansa, ulottavat tämän tilan monenlaiset kytkökset lonkeronsa johtajan aina suhteelliseen autonomiaan, identiteettiin ja vuorovaikutukseen sekä valta-asemiin. Ahonen tuo nämä yhteydet väitöskirjassaan esiin.

Ahosen mukaan johtajan on kyettävä säätelemään johtajuuttaan sen mukaan, ketä sosiaalisessa tilassa toimii ja kuinka suuri on toimijoiden suhteellinen työhön liittyvä autonomia. Johtamisessa on tärkeää se sosiaalinen tila, jossa konkreettisia johtamistoimia tehdään. Usein johtajan omaamien koulun sisäisten suhteiden tila ei ole verrannollinen johtajan ja koulun ulkopuolisen suhteen kanssa. Ne eivät ole symmetrisiä eivätkä pysyviä, vaan alati muutoksessa. Siksi ne vaativat johtajuuden sosiaalisessa tilassa erityistä tarkkaavaisuutta.

Tutkimus nojaa diskurssianalyysiin, joka tarjoaa monitasoisen mahdollisuuden tekstien analysointiin ja tulkintaan. Ahonen ankkuroi itsensä kieleen todellisuuden välittäjänä. Rehtoreiden kertomusten analysointi vie tutkijan analysoimaan paitsi tekstiä, myös tekstien välejä, äännähdyksiä, taukoja jne. Tutkijan vastuu kasvaa suureksi, koska hän tulkitsee teoriakehityksestään myös sellaista, jota ei teksteissä varsinaisesti ole.

Tutkimus tarjoaa sosiaalisen tilan analyysin ohella tiiviin teoriakatsauksen oppilaitosjohtamisen tutkimuksesta. Katsaus osoittaa johtajuuden tutkimuksen monet virtaukset ja suunnat. Jotkut tutkijat lähestyvät teemaa strategisen johtajuuden kautta, jotkut muutosjohtajuuden tai johtajuuden sisältöanalyysin kautta. Käsiteltävä tutkimus tuo tähän mielenkiintoisen lisän, koska hän etsii johtajan identiteettiin vaikuttavia sosiaalisia ja vuorovaikutteisia tekijöitä. $\mathrm{Ne}$ kumpuavat rehtoreiden kirjoittamista teksteistä sekä haastatteluista. Aineiston koon huomioon ottaen, on tulosten tulkinnassa 
kyse pikemminkin kuvausten ja analyysien todellistamisesta, todellisuuden mukaisuudesta kuin yleistettävyydestä.

Aineistosta käy ilmi, että monen rehtorin identiteetin taustalla on opettajuus. Niinpä useassa tapauksessa havaitaan, että rehtorin toimintaorientaatio heiluu opettajuuden ja johtajuuden välillä. Konkreettisessa johtamistyössä tämä asetelma ei ole helppo, koska rehtorilta edellytetään kykyä irrottautua opettajuudesta. Hänen on kyettävä katsomaan sosiaalista tilaansa oman tehtävänsä, johtajuuden, kautta.

Tutkija esittää johtamisen tutkimukselle uuden haasteen: johtamistutkimusta dominoivalle liikkeenjohdolliselle paradigmalle tulee etsiä oppilaitoksiin sopivaa vaihtoehtoista näkökulmaa, jossa vuorovaikutuksellisuus ja oppilaitosten toimintaympäristön erityisyydet voidaan ottaa paremmin huomioon. Liikkeenjohdollinen johtajuusorientaatio ei Ahosen mukaan oikein istu oppilaitosjohtamiseen. Tämä väitöskirja on mielestäni lupaava tutkimus avaamaan toista näkökulmaa, joka liikkeenjohdon paradigmaa täydemmin voi tuottaa arjen johtajuuden tukea ja toimintaympäristön analyysia. Sosiaalisen tilan analysointi voi olla hedelmällinen väline myös oppilaitosjohtajuuden kehittämiseen.

\section{Aki Ojakangas}

\section{Kolmas ikä elämän parasta aikaa?}

Ilka Haarni (2010). Kolmas elämä. Aktiiviset eläkeläiset kaupungissa. Gaudeamus.

$\mathrm{K}_{\mathrm{o}}$ nyt osana Ikainstituutissa toteunyt osana Ikäinstituutissa toteutettua ikäihmisten vapaaehtoistoiminnan tutkimushanketta Vastavuoroisuus, vertaisuus, osallisuus (Vavero). Raha-automaattiyhdistyksen rahoittamassa hankkeessa Haarni tutki eläkeikäisten osallistumista vapaaehtoistoimintaan kyselyn ja etnografisen tutkimusmetodin avulla.

Toteutus oli 12000 asukkaan pääkaupunkiseudun lähiössä, jonka Haarni nimesi "Lähiläksi”". Lähiö on itsessään kuin pieni kaupunki: siellä ovat tarjolla kaikki palvelut.

Kolmannella elämällä Haarni tarkoittaa työiän ja varsinaisen vanhuuden väliin sijoittuvaa elämänvaihetta, jonka tutkija Peter Laslett kuvaa "vapauksien elämänvaiheena". Ominaisuutena on suhteellisen hyvä terveys ja toimintakykyisyys, kun vanhuus on laslettilaisin määrityksin hoivaa edellyttävä vaihe, ensin neljäs ja sitten jo pyörätuolissa tai sängyn pohjalla viides ikä. Joku Haarnin 22 haastatellusta luonnehtikin kolmatta ikää elämän parhaaksi ajaksi.

\section{Organisoitu toiminta kriteerinä}

Haarni on rajannut tutkimuksensa eläkeikäisiin, jotka osallistuvat eriasteisesti organisoituun toimintaan. Sellaisia hän on luokitellut neljä perustyyppiä: yhdistystoiminnan, harrastamisen, vapaaehtoistyön ja omaehtoisen kokoontumisen.

Kun Seppo Niemelä luotsasi oikeusministeriössä hallituksen demokratian ja kansalaisaktiivisuuden politiikkaohjelmaa, rajat olivat tiukemmat. Kansalaisaktiivisuus määrittyi järjestötoiminnassa luottamustehtäviin, sen sijaan tapahtumiin tai toimintaan osallistuminen ei ollut riittävä kriteeri.

Haarni myöntää kirjassaan, että aktiivisuudella ja osallistumisella voidaan ymmärtää kovin monenasteista vireyttä. Haastateltava ja haastattelija voivat ymmärtää sanat eri tavalla. Aktiivisuus onkin veteen piirretty viiva. Tutkimuksen ulkopuolella on nimittäin kaikki se aktiivisuus, joka kohdistuu esimerkiksi kanssakäymiseen sukulaisten kanssa, lastenlapsista huolehtiminen, omaehtoinen harrastaminen kuten lukeminen ja kättentaitojen ylläpito tai ei-organisoitu liikunta ja ulkoilu.

Organisoidun toiminnan ulkopuolella oleviakin on paljon, heitä jotka viihtyvät yksityisyydessään, pitävät kotona ja kesämökillä puuhastelusta, marjastamisesta tai ystävien kanssa kanssakäymisestä. Missä siis on toimeliaisuuden ja toimettomuuden raja? Terveyden vuoksi estyneitä ja yksinäisyydestä kärsiviä lienee heitäkin.

Tai mikä on toimeliaisuuden intensiteetin merkitys: mukana jossakin kerran viikossa vai joka päivä jossakin?

Ilka Haarni seurasi eläkeikäisten toimintaa menemällä heidän 